\title{
The Value and Attributes of an Effective Preparatory English Program: Perceptions of Saudi University Students
}

\author{
Maram George McMullen ${ }^{1}$ \\ ${ }^{1}$ English Language Center Yanbu, Yanbu University College, Yanbu Al-Sinaiyah, Saudi Arabia \\ Correspondence: Dr. Maram George McMullen, ELCY@ Yanbu University College, Yanbu Al-Sinaiyah, P.O. \\ Box 31387, Saudi Arabia. Tel: 96-650-634-4690. E-mail: mcmullenm@rcyci.edu.sa
}

Received: April 3, 2014 Accepted: May 8, 2014 Online Published: June 13, 2014

doi:10.5539/elt.v7n7p131 URL: http://dx.doi.org/10.5539/elt.v7n7p131

\begin{abstract}
This study investigates the effects of gender and geographical location on the perceptions of Saudi university students regarding the value of preparatory English programs and their attributes. Data was collected during the fall of 2013 from three sample universities in the Kingdom of Saudi Arabia (KSA) using an online survey as the instrument. Participants in the study $(\mathrm{N}=479)$ were all enrolled in similar preparatory year English programs in the kingdom and totaled one hundred eighty-four male students and two hundred ninety-five female students. Encouraging results from this study suggest that Saudi university students do realize the value of a preparatory year English program. In most cases, they share common perceptions about which attributes are needed to insure the success of any such program. In some cases, there are significant differences based on gender and geographical location. While research studies on the specific language skills of Saudi university students are increasing steadily each year, the number of studies on preparatory English programs in Saudi Arabia is limited. This study marks the first kingdom-wide, large-scale quantitative analysis study on the programs themselves.
\end{abstract}

Keywords: preparatory year program, Saudi Arabia, geographical location, gender, language learning

\section{Introduction}

The Kingdom of Saudi Arabia currently has 25 government universities, 27 private universities and colleges, and many other training institutions which all offer an intensive preparatory year English program for its students (http://www.mohe.gov.sa). These programs were designed because educational administrators deem them necessary and valuable. In fact, the status of the English language in the Saudi educational system is quite well known. "Policy-makers, stakeholders, and other decision-making bodies in Saudi Arabia view the English language as an important tool for the development of the country in terms of both international relations and scientific-technological advancement. In Saudi Arabia, English has the official status as the primary foreign language and the country continues to show considerable interest in English language programs" (Al-Seghayer, 2014, p. 143). Indeed, English is the only foreign language taught in Saudi Arabian public schools and it is often used as the medium of instruction in both private and public universities. In short, English is considered a prestigious skill both in and out of school (Al-Kubaidi, 2014, p. 83) and, as such, there is an ever-growing demand for it in the kingdom (Al-Haq \& Smadi, 1996, p. 308).

To that end, the Saudi Ministry of Education has identified eleven goals for teaching English in Saudi Arabia, including "to enable students to acquire basic language skills, to develop student awareness of the importance of English as a means of international communication, to develop students' positive attitude towards learning English, and to enable students to acquire the necessary linguistic competence required in different professions" (http://www.slideshare.net).

With these national goals in mind, preparatory year English programs began to develop in earnest during the last few decades, starting with King Fahd University of Petroleum and Minerals which was the first in 1964. Since then, more and more preparatory year English programs have begun to sprout up throughout the kingdom. Typically, only the best and the brightest high school students are accepted at government universities in Saudi Arabia since higher education is tuition-free and only a limited number of places are available. For example, King Saud University in Riyadh does not accept "students that scored less than 92 percent in their entrance examinations" and at King Abdul Aziz University in Jeddah, "students with less than 95 percent pass marks are also frequently turned away" (Naffee, 2013). This leaves the private sector with the challenge of educating high 
school graduates with less impressive results. However, teachers at both private and public universities in Saudi Arabia have noted that they are instantly struck by a remarkable gap between expectations based on stringent admission requirements and the actual English proficiency of their students which they first encounter in the classroom.

This gap might be explained by the language learning environment that many Arab students experience in high school, namely: "teacher-centered rather than learner-centered activities; students' aptitude, initial preparedness and motivation; compartmentalization vs. whole language approach; emphasis on rote learning; [and limited] exposure to English" outside the classroom (Fareh, 2010, pp. 3602-3603).

Clearly, both the educators and the policy-makers in Saudi Arabia see the on-going need for preparatory English programs in the kingdom, but do the Saudi university students themselves see the need and do they perceive the English language to have the same value as all these decision makers? This question leads to an additional inquiry: what attributes do Saudi university students believe constitute a good preparatory year program? While there is a steadily growing amount of literature on the language skills of Saudi preparatory year students - and even a few recent studies focusing on individual preparatory year programs (Al-Seweed \& Daif-Allah, 2012; Al-Shumaimeri \& Al-Ghamdi, 2009; Al-Shumaimeri, 2011; Al-Shumaimeri, 2013; Al-Qahtani, 2013) - there has been no national quantitative analysis research study to date which seeks to analyze these programs. In order to find substantive answers to the probing questions raised here, a large-scale action research study was conducted in the fall of 2013, revealing the varied perceptions of Saudi university students across the kingdom.

\section{Method}

\subsection{Research Questions}

Four specific research questions were used to drive the current study:

Question 1: Does geographical location have any effect on the perceived value of a preparatory English program from the perspective of Saudi university students?

Question 2: Does gender have any effect on the perceived value of a preparatory English program from the perspective of Saudi university students?

Question 3: Does geographical location have any effect on what is perceived to be the attributes of a good preparatory English program?

Question 4: Does gender have any effect on what is perceived to be the attributes of a good preparatory English program?

\subsection{Hypotheses}

In order to determine if geographical location or gender have any effects on how Saudi students perceive the value of a preparatory year English program and what they perceive are the attributes of an effective program, two null hypotheses were formed stating there is no relationship between the independent variables and the dependent variables. In this study, the independent variables were geographical location and gender. The dependent variables were the perceived value and attributes of a good preparatory English program.

\subsection{Participants of the Study}

In order to obtain samples which were representative of the whole population of Saudi EFL university students, the participants for this study $(\mathrm{N}=479)$ were chosen from three universities across the kingdom which offer very similar preparatory year English programs. One university was chosen from the northwest of Saudi Arabia, one from the capital city of Riyadh in the central region, and one from Jeddah, a large, metropolitan city on the Red Sea coast. All three universities have both a male and a female campus as education is segregated in the kingdom. All students take 300 hours of classroom English per semester and all are taught by teachers of mixed nationalities, Saudi and non-Saudi.

\subsection{Procedures for Collecting the Data: The Instrument}

An online survey was created by the researcher using Survey Planet to collect the data from three female and three male campuses. All of the data was collected between November and December 2013.

\subsection{Procedures for Analyzing the Data}

In this study, t-tests were conducted using Microsoft's Excel program to determine if there were any significant differences between the samples. First, differences between male and female samples at individual universities were studied, and then differences between geographic samples were analyzed. Procedures included a comparison of the mean scores, $\mathrm{p}$ values, and the standard deviations of the groups. To determine significance 
throughout the study, the standard of $p<.05$ was used. This means that a result was considered statistically significant if it could have occurred by chance fewer than 5 times out of 100 .

\section{Results}

\subsection{The Value of a Preparatory English Program}

Students who participated in this study were asked (Q1) if they believe preparatory year English programs are needed in Saudi Arabia, (Q2) if they believe all high school graduates in KSA need to take a full year of preparatory English before entering their majors, (Q17) if they were satisfied with the preparatory year English program at their university, and (Q20) if they believe that one day these programs will become obsolete due to the increasing proficiency of Saudi high school students. Results to the questions related to value are as follows:

Table 1. Univ A results/percentages of Saudi students who agree or strongly agree

\begin{tabular}{lllll}
\hline \multirow{2}{*}{ Survey Qs Relating to Value } & Univ A & Univ A & Univ A & Univ A \\
& Female $(\mathrm{n}=229)$ & Male $(\mathrm{n}=39)$ & $\mathrm{M}$ & P value \\
\hline Q1-prep year is necessary & 86 & 85 & 85.5 & .865 \\
Q2-sts need one full year & 84 & 64 & 74 & $* * .003$ \\
Q17-sts are satisfied & 71 & 67 & 69 & .610 \\
Q20-no need in the future & 69 & 59 & 64 & .219 \\
\hline
\end{tabular}

** very statistically significant

* statistically significant

Table 2. Univ B results/percentages of Saudi students who agree or strongly agree

\begin{tabular}{lllll}
\hline \multirow{2}{*}{ Survey Qs Relating to Value } & Univ B & Univ B & Univ B & Univ B \\
& Female $(\mathrm{n}=17)$ & Male $(\mathrm{n}=103)$ & $\mathrm{M}$ & P value \\
\hline Q1-prep year is necessary & 94 & 93 & 93.5 & .881 \\
Q2-sts need one full year & 48 & 76 & 62 & $* .017$ \\
Q17-sts are satisfied & 70 & 77 & 73.5 & .529 \\
Q20-no need in the future & 42 & 62 & 52 & .121 \\
\hline
\end{tabular}

Table 3. Univ C results/percentages of Saudi students who agree or strongly agree

\begin{tabular}{lllll}
\hline \multirow{2}{*}{ Survey Qs Relating to Value } & Univ C & Univ C & Univ C & Univ C \\
& Female $(\mathrm{n}=49)$ & Male $(\mathrm{n}=42)$ & $\mathrm{M}$ & P value \\
\hline Q1-prep year is necessary & 100 & 96 & 98 & .159 \\
Q2-sts need one full year & 84 & 78 & 81 & .465 \\
Q17-sts are satisfied & 74 & 76 & 75 & .826 \\
Q20-no need in the future & 53 & 55 & 54 & .849 \\
\hline
\end{tabular}

Table 4. Total KSA value results separated by gender

\begin{tabular}{lllll}
\hline Survey Qs Relating to Value & $\begin{array}{l}\text { Total female } \\
\text { M }\end{array}$ & $\begin{array}{l}\text { Total female } \\
\text { Sd }\end{array}$ & $\begin{array}{l}\text { Total male } \\
\text { M }\end{array}$ & $\begin{array}{l}\text { Total male } \\
\mathrm{Sd}\end{array}$ \\
\hline Q1-prep year is necessary & 93.33 & 7.02 & 91.33 & 5.69 \\
Q2-sts need one full year & 72.00 & 20.78 & 72.67 & 7.57 \\
Q17-sts are satisfied & 71.67 & 2.08 & 73.33 & 5.51 \\
Q20-no need in the future & 54.67 & 13.58 & 58.67 & 3.51 \\
\hline
\end{tabular}


Table 5. Total KSA value results (mixed gender)

\begin{tabular}{lll}
\hline Survey Qs Relating to Value & $\begin{array}{l}\text { Total KSA } \\
\text { M }\end{array}$ & $\begin{array}{l}\text { Total KSA } \\
\text { SD }\end{array}$ \\
\hline Q1-prep year is necessary & 92.33 & 6.33 \\
Q2-sts need one full year & 72.33 & 9.61 \\
Q17-sts are satisfied & 72.50 & 3.12 \\
Q20-no need in the future & 56.67 & 6.43 \\
\hline
\end{tabular}

\subsection{Attributes of a Good Preparatory English Program}

Students in this study were also asked (Q6) if they believe their program needs more speaking, (Q7) more writing, (Q10) if their program uses a variety of assessment tools, (Q11) if they believe that 20 hours of English per week is too much, (Q12) if they believe universities should provide a relaxed setting outside of the classroom such as an English Club for students to practice English, (Q14) if they believe their university provides sufficient student learning support/private tutorial sessions, and (Q15) if they believe the required hours of English lectures should be reduced to give students more time to avail themselves to the student support program. Results to these specific questions on the attributes of a good preparatory English program are as follows:

Table 6 . Total KSA attributes results by separated by gender

\begin{tabular}{lllll}
\hline Survey Qs Relating to Attributes & Total female & $\begin{array}{l}\text { Total female } \\
\text { M }\end{array}$ & $\begin{array}{l}\text { Total male } \\
\text { M }\end{array}$ & $\begin{array}{l}\text { Total male } \\
\text { Sd }\end{array}$ \\
\hline Q-need more speaking & $89.00^{*}$ & 5.57 & 81.33 & 4.04 \\
Q7-need more writing & 70.67 & 7.51 & 76.33 & 7.37 \\
Q10-good mix of test materials & 68.33 & 12.34 & 74.67 & 9.29 \\
Q11-20 hrs of English is too much & $54.33^{* *}$ & 8.08 & 72.00 & 6.08 \\
Q12-club facilities needed & $84.00^{*}$ & 7.21 & 74.33 & 11.55 \\
Q14- helpful support program & $82.33^{* *}$ & 6.11 & 69.00 & 11.36 \\
Q15-reduced hrs needed to seek support & 62.00 & 3.00 & 63.00 & 6.93 \\
\hline
\end{tabular}

Table 7. Total KSA attributes results (mixed gender)

\begin{tabular}{lll}
\hline Survey Qs Relating to Attributes & Total KSA & $\begin{array}{l}\text { Total KSA } \\
\text { M }\end{array}$ \\
\hline Q6-need more speaking & 85.17 & 3.79 \\
Q7-need more writing & 73.50 & 5.68 \\
Q10-good mix of test materials & 71.50 & 8.19 \\
Q11-20 hrs of English is too much & 63.17 & 1.04 \\
Q12-club facilities needed & 79.17 & 8.74 \\
Q14-helpful support program & 75.67 & 8.04 \\
Q15-reduced hrs needed to seek support & 62.50 & 2.29 \\
\hline
\end{tabular}

\subsection{The Most Important Factor in Good Language Learning}

Saudi students were given three questions asking them whether (Q3) the book, (Q4) the teacher, or (Q5) the student is the most important factor in good language learning. Students responded almost unanimously across the kingdom, indicating their belief that the teacher is the most important key to their success as language learners. See graph on the next page: 


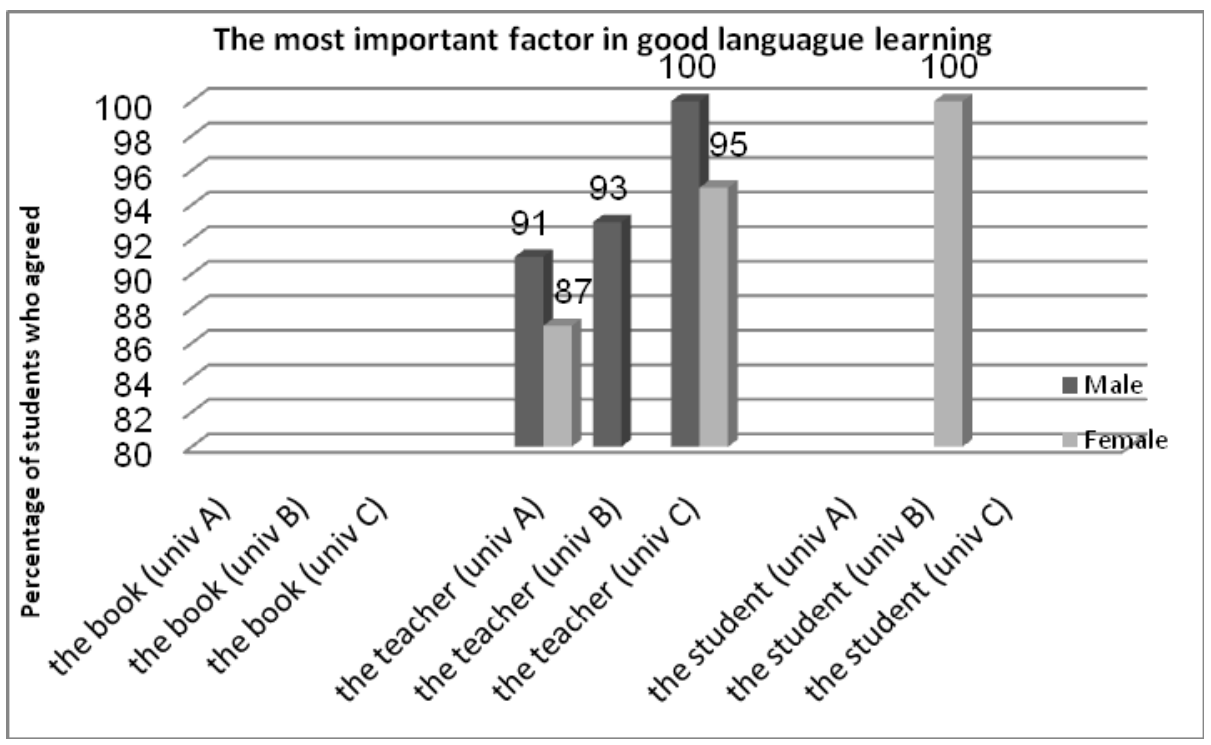

Figure 1. The most important factor in good languague learning

\section{Discussion of Results}

\subsection{Survey Questions Related to the Value of a Preparatory English Program}

Results for survey Q1 were overwhelming - over $85 \%$ of Saudi university students who participated in the survey responded that they believe preparatory year English programs are necessary. Likewise, $67-77 \%$ of the participants responded favorably to Q17, indicating that they were satisfied with their English language program.

For Q2, whether or not most high school graduates in KSA need one full year of an English preparatory year program, responses varied significantly in Riyadh at University B and in the northwest of Saudi Arabia at University A. In the northwest of the kingdom, $84 \%$ of the female students indicated they believed a full year of English was necessary whereas only $64 \%$ of their male counterparts agreed - a very statistically significant difference. In Riyadh, it was almost the opposite, with only $48 \%$ of the female students indicating they thought a full year was needed and $76 \%$ of the male students demonstrating their belief that a full year is needed. However, since there were only 17 female respondents in Riyadh compared to 103 male respondents, results from the female campus in Riyadh tend to be inconclusive. Looking to University $\mathrm{C}$ in Jeddah, we see that the results are much more similar to University A with $84 \%$ of the female students indicating their belief that a full year is needed and $78 \%$ of the male students in Jeddah concurring.

As for Q20, whether or not one day Saudi Arabia will no longer need any more preparatory year English programs because students are starting to learn more and more English on their own, only about half of the students surveyed agreed. Again, female students at University B differed from the other five campuses with their responses dipping below $50 \%$ for those who agreed. One might interpret this as meaning that the female students at University B have more realistic expectations about the future proficiency of Saudi high school graduates or, again, this aberration could be attributed to the small sample size. Either way, low numbers at all six campuses indicates the majority of Saudi university students believe that preparatory year English programs will be needed in their country for quite some time.

\subsection{Survey Questions Related to the Attributes of a Good Preparatory English Program}

When asked if they believed more practice with speaking and writing was needed in the classroom (Q6 and Q7), $77-94 \%$ indicated that more speaking was needed and $63-82 \%$ indicated that more writing was needed. The overwhelming majority of Saudi university students indicated that their preparatory year English program uses a good variety of assessment tools (Q10), that relaxed settings such as an English Club should be provided to give students an opportunity to use English outside of the classroom (Q12), and that their university's student learning support program was helpful (Q14). However, there was a very statistically significant difference between female and male Saudi students with $82 \%$ of the females in the kingdom reporting that they found their student learning support program helpful and only $69 \%$ of the male students concurring.

When asked whether the standard 20 hours of English language classes per week was too much (Q11), responses 
varied throughout the kingdom with $45-79 \%$ agreeing the amount is excessive, especially the male students. Yet, when we consider that the national average was only $63 \%$, the response was not the overwhelming majority that some of us would have expected. It should be noted that, even if the percentage had been higher, administrators in the kingdom are not apt to reduce these hours simply due to student opinion. In fact, the specified number of hours is derived from the Association of Language Testers of Europe (ALTE) which has aligned their language examinations with the Common European Framework (CEF). ALTE has provided general recommendations on the number of guided teaching hours needed to fulfill the aims of each CEF level. Guided teaching hours are the hours during which the learner is in a formal learning context such as the classroom. The number of hours needed for different learners varies greatly, depending on a range of factors including "age and motivation, background, amount of prior study and extent of exposure to the language outside the classroom, and the amount of time spent in individual study" (Pearson, 2013, p. 7). In light of these factors, nearly all preparatory year courses in the Kingdom of Saudi Arabia require 300 classroom hours per semester which is 20 hours per week. It is standard practice and most teachers in KSA would agree that considering the teaching context it is an appropriate amount of hours for Saudi students.

\subsection{Survey Questions Related to the Most Important Factor in Good Language Learning}

When asked about whether the book (Q3), the teacher (Q4), or the student (Q5) was the most important factor in good language learning, five out of six campuses responded that the teacher is the key. The only campus which answered differently was the female campus at University B in Riyadh which only had 17 participants. As stated previously, it is entirely possible that the small sample size is the reason for this deviation. It could be that this result would have been more comparable to the other campuses if more students had participated in the survey. However, there is another possible explanation for this response. It is also entirely possible that the female students at University B in Riyadh are simply more autonomous learners than their counterparts at any of the other campuses in the kingdom. Perhaps, if more female students had participated in the survey, they too would have agreed that the student is the key to his/her own learning.

\subsection{Reliability and Validity of Results}

With any quantitative analysis research project, considerable reflection is needed to determine if the data collected can be trusted. It is well known that "one central issue in considering the reliability and validity of questionnaire surveys is that of sampling. An unrepresentative, skewed sample, one that is too small or too large, can easily distort the data" (Cohen, Manion, \& Morrison, 2003, p. 129). Because observations for this study were taken from three different universities across the kingdom and because the kingdom-wide sample was neither too large nor too small $(\mathrm{N}=479)$, we can surmise that generally speaking sampling issues were not a problem associated with this study.

As far as reliability is concerned, this study had incontrovertible results. Establishing reliability involves two domains. "Internal reliability involves asking questions such as: Were the methods for collecting, analyzing, and interpreting the data consistent? Would the same results be obtained by other researchers using the same analysis? External reliability, on the other hand, raises the following question: Could an independent researcher reproduce the study and obtain results similar to the original study?" (Burns, 1999, p. 21). Because the methods for collecting, analyzing, and interpreting the data for this study were all meticulously consistent, it is highly likely that other researchers would have produced the same results - a strong indication that the results of this study are in fact reliable.

As for the validity of this or any survey, we need to consider two viewpoints: "First, whether the respondents who complete the questionnaires do so accurately, honestly and correctly; and second, whether those who fail to return their questionnaires would have given the same distribution of answers as did the returnees" (Cohen, Manion, \& Morrison, 2003, p. 128). From the first viewpoint, the researcher in this study is extremely confident that those who participated understood the questions because they completed the survey in a preparatory English class or lab under the supervision of a teacher who was available to answer any of their questions. Furthermore, the students knew their teacher would never see their answers, so there was no reason for the respondent to exaggerate or camouflage their true response in hopes of gaining teacher approval. As far as speculation on whether those who were absent would have responded in much the same way as their classmates, I believe that the sample sizes were large enough from five out of the six campuses surveyed to conclude categorically that absentees would have answered the same way. However, in the case of University B which only had 17 female respondents due to tapering attendance at the end of the semester when this survey was administered, one might question the validity of the results as such a small response leads us to wonder if only the high-achievers were present and participated and whether or not the absentees would have responded in the same way. Nevertheless, 
the results from the female campus at University B are the only ones that raise any questions and these concerns are greatly diminished when taken in consideration with the all the other results received from the other five campuses.

With this minor limitation in mind, the results of this large-scale study were nonetheless conclusive. Statistical analysis clearly indicated that — in response to Research Questions One, Two, Three, and Four - there were a few statistically significant differences based on gender and geographical location pertaining to the Saudi student's perceived value of a preparatory year English program and what its best attributes were (see starred items in tables 1, 2, and 6). However, overall, there was also much consensus of opinion.

\section{Conclusion}

\subsection{Implications}

The implications of this study are widespread, reaching educators and policy-makers inside the preparatory year programs at universities throughout the kingdom of Saudi Arabia and even those in the public and private high school system, where students begin to think more seriously about their English language skills and needs.

\subsubsection{Saudi High School English Program Reform}

In the last decade, educators in Saudi Arabia have been pushing for reform inside Saudi high schools. "The Higher Committee of Education is trying to reform the educational policy of the Kingdom to meet the challenges of education, including the teaching of the English language" (Al-Shumaimeriqtd. in Rahman \& Al-Haisoni, 2003, p. 115). This study confirms the need for that reform, specifically offering statistical proof that students themselves believe they leave high school without the English skills necessary to enter their academic majors. Saudi preparatory English students frequently report to their university teachers that while they used to get "excellent" in high school English classes, they are suddenly shocked to find themselves struggling just to pass their preparatory English course.

\subsubsection{Saudi Philosophical Shift from Exam-Centered to Learner-Centered Behavior}

This study indicates that students themselves are beginning to realize that exams are not the only way to assess their language progress. This is clear when we examine the statistics on whether or not their university offers a good variety of assessment tools. At the same time, any university educator in Saudi Arabia can report that trying to get students to move away from antiquated exam-centered behavior to learner-centered behavior is an uphill battle, yet it is a goal we must continue to address in order to turn these high school graduates into "life-long learners" (Javid et al., 2012, p. 65). In my experience teaching in both Riyadh and in western Saudi Arabia, I believe most university lecturers today realize the value of a learner-centered classroom. However, Saudi university students may not be so convinced. Most have only been exposed to teacher-centered instruction during their high school years where the focus more often than not was on getting good grades instead of on discovering new ways of learning (Ahmad, 2014, p. 98). Many teachers in Saudi Arabia have noted that-in spite of their best pedagogical efforts-Saudi university students continue to focus on test results rather than learning. In order to determine if each new intake of preparatory English students ultimately experiences any philosophical shift from exam-centered to learner-centered behavior by the end of their preparatory year experience, qualitative studies should be conducted at both the start and finish of the program to provide definitive proof.

\subsubsection{Periodic Needs Analysis Studies}

Needs Analysis is "the process of determining the needs for which a learner or group of learners requires a language and arranging the needs according to priorities" (Richards \& Platt, 1992, p. 242). To be succinct, a need is "a gap between 'what is' and 'what should be"" (Witkin et al., 1995, p. 3). Identifying needs and planning how to satisfy them is the cornerstone of good ESP course design. Unfortunately, more often than not, "the policy makers and the syllabus designers of Saudi Arabia fail to design a curriculum or syllabus after conducting a needs analysis program" (Rahman \& Al-Haisoni, 2013, p. 115). This research study takes into consideration the students' perception of what they need from a preparatory English program. Further study is needed to see what the teachers think is needed. Moreover, teachers who teach at both the preparatory year level and the freshmen year level should be consulted. I suggest that a needs analysis study be conducted at every preparatory English program in Saudi Arabia to identify the specific needs of its learners and to assess which ones have a higher priority. Ideally, these needs analysis studies should to be conducted periodically, perhaps every two to three years, to keep abreast of a changing student population. 


\subsubsection{In-Service Training}

Once a needs analysis study is conducted, a parallel in-service teacher training program should be set up immediately to enable teachers to meet the current needs of their students. English language teachers across the kingdom have repeatedly called upon top-management of their institutions to provide more in-service professional development training sessions, a phenomenon noted by researchers in Saudi Arabia for years (Al-Hazmi, 2003; Al-Seghayer, 2005; Khan, 2011; Rahman \& Al-Haisoni, 2013; Zafer, 2002; Zohairy, 2012). Top-management needs to invest in their teachers in order to meet the changing needs of Saudi university students.

\subsubsection{The Power of Positive Thinking}

In a 2008 study of Turkish preparatory year students, researchers found that "forming positive relationships with students was an essential quality of an effective teacher" (Arikan et al., p. 48). Turkish students indicated that an effective English teacher is "friendly, enthusiastic, creative, and humorous," traits identified in similar international studies as well (Brosh, 1996; Cheung, 2006; Park \& Lee, 2006; Shishavan \& Sadeghi, 2009). I believe a similar study in Saudi Arabia would produce the same results. If the teacher creates a positive learning environment for his or her students day after day, the students are more likely to respond positively and take every opportunity to improve their language skills.

\subsection{Recommendations for Future Research}

It is common knowledge that governments throughout the Middle East invest a great deal of their resources in setting up preparatory year English programs and recruiting teachers from all over the world to make them a success-Saudi Arabia is no exception. At the end of the day, opinions may vary about how successful these programs are. Lecturers who teach freshman-level students often question the English proficiency of their students who have just exited the preparatory program. This is a kingdom-wide phenomenon. However, teachers in the preparatory year program who greeted their students fresh out of Saudi high schools can attest to the dramatic change in student proficiency levels they witnessed firsthand in their classroom from the beginning to the end of each semester. My recommendation is that preparatory year programs in Saudi Arabia start to document this transformation in each student's language learning journey. Just as placement tests are routinely administered to a new intake of students, exit tests should also be routinely administered to measure the student's English language proficiency at the end the program. Data should be collected and analyzed to compare these two results.

This study has revealed that Saudi university students do realize the value of a preparatory year English program. They realize that, for the most part, their English proficiency upon graduation from high school is not adequate for them to enter their academic majors. This study has also revealed that, as much as we would like our students to believe that they themselves are the most important factor on the road to their language learning success, the majority of Saudi students still look to the teacher as being the key to how much they will learn during their preparatory year experience. That given, the onus is on top-management to make sure they attract and retain the best educators in the world whether they are found locally or overseas. It also involves making a solemn commitment to in-service professional development, so teachers will be able to provide the service that our students need.

\section{Acknowledgments}

The author would like to thank Dr. FarhatNasar, of Yanbu University College, for conducting the t-tests and offering assistance with the quantitative analysis of the data generated in this study.

\section{References}

Ahmad, A. (2014). Kumaravadivelu's Framework as a Basis for Improving English Language Teaching in Saudi Arabia: Opportunities and Challenges. English Language Teaching, 7(4), 96-110.

Al-Haq, F., \& Smadi, O. (1996). Spread of English and Westernization in Saudi Arabia. World Englishes, 15(3), 307-317.

Al-Hazmi, S. (2003). EFL teacher preparation programs in Saudi Arabia: Trends and Challenges. TESOL Quarterly, 37(2), 341-344.

Al-Kubaidi, M. (2014). The Relationship between Saudi English Major University Students' Writing Performance and Their Learning Style and Strategy Use. English Language Teaching, 7(4), 83-95.

Al-Qahtani, M. (2013). An Analysis of the Effectiveness of a Preparatory Year Program in Learning English Among Saudi Students. Research paper presented at the 7th International Technology, Education and 
Development Conference, Valencia, Spain.

Al-Seghayer, K. (2005). Teaching English in Saudi Arabia: Slowly but steadily Changing. In G. Braine (Ed.), Teaching English to the World. Mahwah, NJ: Lawrence Erlbaum Association.

Al-Seghayer, K. (2014). The Actuality, Inefficiency, and Needs of EFL Teacher-Preparation Programs in Saudi Arabia. International Journal of Applied Linguistics \& English Literature, 3(1), 143-151.

Al-Seweed, M., \& Daif-Allah, A. (2012). An Intensive Preparatory English Learning Module for PYP Students: Benefits and Challenges. Journal of Arabic and Human Sciences, 6(1), 1-22.

Al-Shumaimeri, Y. (2003). A study of classroom exposure to oral pedagogic tasks in relation to the motivation and performance of Saudi secondary learners of English in a context of potential curriculum reform (Unpublished PhD thesis). University of Leeds, Leeds.

Al-Shumaimeri, Y., \& Al-Ghamdi, F. (2009). Perceptions of Saudi PYP students about the IEP at King Saud University. Research paper presented at IATEFL Annual Conference, Cardiff, UK.

Al-Shumaimeri, Y. (2011). Perceptions of Saudi preparatory year students about the intensive English program. College of Arts Annals, Ain Shams University, 39, 565-593.

Al-Shumaimeri, Y. (2013). The Effect of an Intensive English Language Program on First Year University Students' Motivation. Journal of Educational \& Psychological Sciences, 14(1), 11-32.

Arikan, A., Taşar, D., \& Saraç-Süzer, H. (2008). The Effective English Language Teacher from the Perspectives of Turkish Preparatory School Students. Education and Science, 33(150), 42-51.

Brosh, H. (1996). Perceived characteristics of an effective language teacher. Foreign Language Annals, 29(2), 25-38.

Burns, A. (1999). Collaborative Action Research for English Language Teachers. Cambridge: Cambridge University Press.

Cheung, H. (2006). The measurement of teacher efficacy: Hong Kong primary in-service teachers. Journal of Education for Teaching, 32(4), 435-451.

Cohen, L., Manion, L., \& Morrison, K. (2003). Research Methods in Education (5th ed.). London: Routledge Falmer.

Fareh, S. (2012). Challenges of teaching English in the Arab world: Why can't EFL programs deliver as expected? Procedia Social and Behavioral Sciences, 2(2), 3600-3604.

Javid, C., Farooq, M., \& Gulzar, M. (2012). Saudi English-Major Undergraduates and English Teachers' Perceptions Regarding Effective ELT in the KSA: A Comparative Study. European Journal of Scientific Research, 85(1), 55-70.

Khan, I. (2011). Professional development of English teachers: The Saudi Arabian context. Interdisciplinary Journal of Contemporary Research in Business, 3(2), 1583-1591.

Ministry of Education. (n.d.). Study in Saudi Arabia. Retrieved from http://www.mohe.gov.sa/en/studyinside/Government-Universities/Pages/default.aspx

Ministry of Education. (n.d.). The General Goals of Teaching English in Saudi Arabia. Retrieved from http://www.slideshare.net/tamma07/general-goals-for-teaching-english-in-saudi-arabia-pdf

Naffee, I. (2013). Saudi Universities preparing graduates for labor market. Arab News. Retrieved from http://www.arabnews.com/news/448284

Park, G. P., \& Lee, H. W. (2006). The characteristics of effective English teachers as perceived by high school teachers and students in Korea. Asia Pacific Education Review, 7(2), 236-24.

Pearson, \& Longman. (2013). A Teacher's Guide to the Common European Framework. Retrieved from http://www.euddansk.dk/wp-content/uploads/2013/04/cefguide.pdf

Rahman, M., \& Al Haisoni, E. (2013). Teaching English in Saudi Arabia: Prospects and Challenges. Academic Research International Journal, 4(1), 112-118.

Richards, J., \& Platt, H. (1992). Dictionary of Language Teaching and Applied Linguistics. Malaysia: Longman.

Shishavan, H., \& Sadeghi, K. (2009). Characteristics of an Effective English Language Teacher as Perceived by Iranian Teachers and Learners of English. English Language Teaching, 2(4), 130-143. 
Witkin, B. R., \& Altschuld, J. W. (1995). Planning and Conducting Needs Assessments: A Practical Guide. Sage Publications: Thousand Oaks, CA.

Zafer, A. (2002). A Survey of Saudi School Teachers' and College Professors' Perspectives on topics and Roles to Emphasize in English as a Foreign Language in Teacher Preparation Course (Unpublished doctoral dissertation). University of Kansas, Lawrence, Kansas.

Zohairy, S. (2012). Professional development challenges and possible solutions. In W. Al-Amri, H. Noor, \& I. McGee (Eds.), Saudi Preparatory Year English Program: The Future and Beyond: Student, teacher, pedagogy and curricular issues. Madinah, Taibah University.

\section{Copyrights}

Copyright for this article is retained by the author(s), with first publication rights granted to the journal.

This is an open-access article distributed under the terms and conditions of the Creative Commons Attribution license (http://creativecommons.org/licenses/by/3.0/). 